\title{
Pre-eruptive magmatic processes of Zao volcano: timescales of multiple magma mixings revealed by orthopyroxene phenocrysts
}

\author{
MOTOHIRO SATO ${ }^{1}$ AND MASAO BAN ${ }^{1}$ \\ ${ }^{1}$ Graduate School of Science and Technology, Yamagata \\ Univ., Yamagata 990-8560, Japan \\ ${ }^{2}$ Faculty of Science, Yamagata Univ., Yamagata 990-8560, \\ Japan (*correspondence: ban@sci.kj.yamagata-u.ac.jp)
}

In Zao volcano, NE Japan, the phreato-magmatic to phreatic eruptions occurred repeatedly from Okama crater (ca. AD1200 to present) and precursory phenomena, such as volcanic tremors and earthquakes have been observed since 2013. To reveal the magma plumbing system more in detail, we studied compositional zoning and diffusion modeling of orthopyroxene phenocrysts from Okama crater eruption products $(\mathrm{Okp})$ from Zao volcano.

Juvenile bomb samples are medium- $\mathrm{K}$ and calc-alkaline series basaltic andesite to andesite $\left(56-57 \% \mathrm{SiO}_{2}\right)$, including plagioclase, orthopyroxene, clinopyroxene and magnetite as phenocryst. Phenocrysts show wide compositional ranges and multiple peaks were identified (i.e. plagioclase: An65,75,88). All products are the mixed rock basically formed by magma mixing basically between two end-member magmas: the low$\mathrm{T}$ end-member magma $\left(60 \% \mathrm{SiO}_{2}, 950-970^{\circ} \mathrm{C}, 150-200 \mathrm{MPa}\right.$, $3 \% \mathrm{H}_{2} \mathrm{O}$, having An-poor plg, Mg-poor px) and the high- $\mathrm{T}$ end-member magma $\left(52-53 \% \mathrm{SiO}_{2},>1040^{\circ} \mathrm{C}, 200-250 \mathrm{MPa}\right.$, $4-5 \% \mathrm{H}_{2} \mathrm{O}$, having An-rich plg, Mg-rich px and olv). The mixed magma would be formed mainly between both endmember magmas.

Based on zoning profiles of $\mathrm{Mg \#}, \mathrm{Al}$, and $\mathrm{Cr}$ in orthopyroxene phenocrysts, low- $\mathrm{T}$ and modified high- $\mathrm{T}$ magmas mixing is recognized other than low- and high- $T$ magmas mixing. The modified high-T magma was formed by incorporation of the mixed magma into the high- $\mathrm{T}$ magma when the latter injected into the former. We estimated the residence time of both cases of the mixing by $\mathrm{Fe}-\mathrm{Mg}$ diffusion modeling applied to the $\mathrm{Mg \#}$ zoning of orthopyroxene. The estimated timescales are mostly a few decades for low- and high-T magma mixing and a few days to decades for low-T and the modified high-T magma mixing.

The pre-eruptive processes of the Okp are proceeded as follows. The injection of the high-T magma and mixed with the low-T magma (a few decades before eruption), resulted in the formation of the mixed magma. The injection of the high$\mathrm{T}$ magma into the mixed magma formed the modified high- $\mathrm{T}$ magma tentatively, that mixed with the L-magma (a few decades to a few days before eruption). 